\title{
Assessment of the Mediating Effects of External Integration on Manufactury Firms Operational Performance
}

\author{
Thywill Cephas Dzogbewu' (iD), Samuel Korateng Fianko ${ }^{2}$ iD, Sampson Afrifa Jnr² iD, Nathaniel Amoah ${ }^{3}$ iD \\ ${ }^{1}$ Department of Mechanical and Mechatronics Engineering, Central University of Technology, Free State (South Africa) \\ ${ }^{2}$ Department of Business Support Studies, Central University of Technology, Free State (South Africa) \\ ${ }^{3}$ Department of Business \& Law, Universita degli Studi di Brescia (Italy) \\ tdrogbewn@cut.ac.za, agapesam4@gmail.com,profafrifa21@gmail.com,n.amoab@unibs.it
}

Received: February 2021

Accepted: July 2021

\begin{abstract}
:
Purpose: The purpose of this study was to assess both the direct effect of supply chain integration on firm's operational performance and the mediating effect of external integration (customer integration and supplier integration) on the relationship between internal integration and operational performance among manufacturing firms.
\end{abstract}

Design/methodology/approach: Quantitative survey research design was adopted. A total of thirty (30) manufacturing firms were sampled using cluster sampling. The data was collected using questionnaires from 317 employees in the procurement, account and administration units of the 30 manufacturing firms. Structural Equation Modeling was used to analyze the direct and mediation relationships.

Findings: The results showed that the relationship between internal integration and operational performance was significantly mediated by external integration. It was established that operational performance could only be achieved when manufacturing firms' managers pay critical attention to internal and external integration. A Significant positive relationship also exists between supplier integration and operational performance as well as customer integration and operational performance.

Originality/value: The unique contribution of the current study is the assessment of the mediating effect of external integration constructs (customer integration and supplier integration) as the mediating variable on internal integration and operational performance.

Keywords: supply chain integration, operational performance, manufacturing industry, external integration, internal integration

\section{To cite this article:}

Dzogbewu, T.C., Korateng Fianko, S., Afrifa Jnr, S., \& Amoah, N. (2021). Assessment of the mediating effects of external integration on manufactury firms operational performance. Journal of Industrial Engineering and Management, 14(4), 718-732. https://doi.org/10.3926/jiem.3500 


\section{Introduction}

Today's global market and business environment is characterized by a high degree of uncertainties and complexities which cannot be managed effectively by relying only on the internal capabilities and competencies of organizations (Tavana, Shabani \& Singh, 2019; Fianko, Afrifa Jnr \& Dzogbewu, 2020). In an effort to address this challenge, several manufacturing companies have attempted to improve upon their operations through different manufacturing techniques such as lean technology, business process reengineering, total quality management and others (Georgise, Thobend \& Seifert, 2014). In addition to these strategies, manufacturing firms have realized that there is a need to foster mutual relationships by collaborating with supply chain partners through supply chain integration for better performance while meeting the demands of the customers (Dzogbewu, 2010; Jacobs, Yu \& Chavez, 2016; Ataseven \& Nair 2017).

Supply chain integration describes the practice of aligning business functions within an organisation and that of partners within its supply chain with the aim of reducing cost, achieving customer value and overall performance of all members of the supply chain (Tarifa-Fernandez \& De Burgos-Jimenez 2017). Supply chain integration according to Flynn, Huo and Zhao (2010) is classified into two main groups which are internal and external integration. External integration which is a measure of the degree to which organisations engage and collaborate with their external partners in their operations is made up of customer and supplier integration (Flynn et al. 2010). Internal integration on the other hand describes how organisations structure their internal operations and strategies so as efficiently interact with suppliers to meets the requirements of customers (Kahn \& Mentzer, 1996; Flynn et al., 2010). The adoption of supply chain integration provides several benefits to organisations including an increase in productivity, reduction in cost and lead time, improvement in practical efficiency, quality, satisfaction of the requirements of businesses' and customers' orders in addition to enhancement in competitive advantage and longterm performance (Soliman, 2015; Zhao, Huo, Sun \& Zhao, 2013; Huo, 2012). It implies that supply chain integration could improve on the manufacturing company's operational performance.

Extant literature therefore reveals that there exists a significant relationship between supply chain integration and operational performance. However, this relationship is mixed as some studies confirm a significant positive relationship (Yuen \& Thai, 2017; Perdana, Ciptono \& Setawan, 2018; Flynn et al., 2010; Zhao et al., 2013) and other negative significant relationship (Njagi \& Muli, 2020; Perdana et al., 2018; Han, Lu, Trienekens \& Omta 2013). In spite of the inconsistencies in results on supply chain integration and operational performance, few studies have assessed the mediation effects of supply chain integration constructs and its impact on operational performance (Errassafi, Abbar \& Bennabou, 2019; Somjai, Girdwichai \& Jermsittiparsert, 2019). A review of the literature uncovered that studies on mediation effects have focused on using internal integration to explain/mediate the relationship between external integration and operational performance (Errassafi et al., 2019; Somjai et al., 2019). In the study by Errassafi et al., it was found that internal integration significantly mediates the relationship between customer integration and operational performance, but does not mediate the relationship between supplier integration and operational performance. The current study therefore seeks to examine the mediating effect of external integration constructs such as customer integration and supplier integration on the relationship between internal integration and operational performance. This is because, previous mediation studies on supply chain integration and operational performance have used internal integration as the mediating variable (Errassafi et al., 2019; Somjai et al., 2019). In such a challenging business environment, this study seeks to assess whether external integration (customer and supplier integration) mediate the relationship between internal integration and operational performance or not.

\section{Literature Review}

\subsection{Supply Chain Integration (SCI)}

SCI has over the years become one of the extensively explored concepts in the area of supply chain management. Despite this, there are several definitions of the concept of SCI by different scholars and there seems to be little agreement on the definition of the concept. For instance, according to Leuschner, Rogers and Charvet (2013), SCI is a process where different companies or entities work together through collaboration and cooperation to achieve acceptable outcomes. In another study, SCI was referred to as the strategic collaboration among partners of the 
supply chain to ensure efficacy in processes that create value (Njagi \& Ogutu, 2014). Ebrahimi (2015), referred to SCI as a collaboration which encompasses all players in the supply chain such as customers, suppliers and the focal organizations in which they independently and dependently work together to create customer value through efficiency and cost reduction. Krajewski, Ritzman and Malhotra (2013) defined SCI as an organization of supply chain process in a way that fosters a continuous stream of information along the supply chain. This study defines supply chain integration as the strategic collaboration among organization's internal operations and that of its suppliers and customers to be able to work together independently and dependently to create customer value through efficiency and cost reduction. Supply chain integration for the purpose of this study is grouped under internal integration, supplier integration and customer integration (Flynn et al., 2010).

\subsubsection{Internal Integration}

Internal integration refers to the interactions, communication, and collaboration among the different functional units of an organization for the purpose of achieving cohesion to deliver excellent service to the customer (Zhao, Huo, Selen \& Yeung, 2011). This involves the linkage and integration of information among all departments of an organization including production, marketing, procurement through computerized planning systems (Lee, Kwon \& Severance, 2007). Thus, the exchange of information regularly in supply chain among partners helps them to work as a single unit in positively meeting the needs of the customers and effectively responding to market needs (Zhao et al. 2011). For instance, Lee et al. (2007) argue that information sharing among departments in an organization provides easy access to information on inventory which can be accessed easily on an integrated database which is linked to the production process, marketing activities and other departments in an organization using a computerized system. Further, partners in the supply chain who collaborate and work as a single unit through effective exchange of information have a better capacity to adapt to market changes and preferences far better than others. Huo (2012) therefore argue that firms that have low levels of integration strategies are most likely to have low levels of integration with its external partners such as suppliers and customers and vice versa.

\subsubsection{Customer Integration}

Customer integration according to Tan, Kannan and Handfield (1998) refers to the management of demand through the management of customer complaints, satisfaction improvement and lasting customer relations. Essentially, the central focus of the customer relationship management is exploring the needs, preferences and requirement of the customers in order to better satisfy them (Yousief, 2018). Customer integrations comprise of several activities including establishing problem solving initiatives, direct contacting of customers, addressing complaints of customers, raise the level of customer satisfaction and achieving lasting customer relationships (Sousa, 2003; Tan et al., 1998). According to Flynn et al. (2010) in manufacturing companies, customer integration which among other things include the sharing of demand which enables organizations to have an appreciable comprehension of customer needs as well as a more accurate forecast of the customer and the collaboration of customers in the design of products and service in order to better meet customer needs. This includes providing and sharing relevant and adequate information on products such as orders, status of orders with customers at the stage where products are delivered. There are several benefits of the customer integration such as market share increase, improved product and service differentiation on the market, improved customer loyalty as well as appreciable depth of the needs of the customer and better response to these needs (Wasti \& Jeffrey, 1999).

\subsubsection{Supplier Integration}

As the only source of inputs or raw materials for the carrying out of an organization's operational activities, suppliers play a vital role in the manufacturing of products and service that satisfies customer expectations. In today's business environments, the extent to which firms are able to reduce the cycle and delivery time in addition to managing fluctuation demands depends largely on the extent to which stronger partnership or bond are formed between suppliers and the focal firm. Presently, many manufacturing companies involve suppliers right at the design stage to ensure that the products bring the highest level of satisfaction to customers. Also referred to as backward integration, Zhao et al. (2011) described supplier integration as the collaboration and interaction that exist between organizations and their suppliers for the purpose of achieving effectiveness in supply flows. There are several supplier activities, and these include the involvement of suppliers at the design stage to aid in the design of 
products, setting up of a very robust supplier order processing system which is very responsive, a reliable supplier network that supports a continuous flow of information among suppliers and the planning and management of inventory. Li, Fan, Lee and Cheng, (2015) assert that supplier integration leverages on the capabilities of individual participating organizations (suppliers) to gain significant ongoing benefits. According to Echtelt, Wynstra, Weele \& Duysters (2008) because SCI is characterized by different features such as sharing of information, trust, shared technologies, process integration, capacity building for suppliers, risk and reward sharing, it produced immense benefit such as improved decision making and increased performance.

\subsection{Operational Performance}

Operational performance refers to the measurable aspects of the outcomes of an organization's processes, such as reliability, production cycle time, and inventory turns (Azim, Ahmed \& Khan, 2015). Within the context of supply chains, operational performance is referred to as metrics that quantifies the effectiveness and efficiency of the supply chain process (Maestrini, Luzzini, Maccarrone \& Caniato, 2017). Operational performance have been measured by different scholars from different viewpoints. For instance, in the case of Wang, Chang \& Wang (2009) efficiency was the indicator for the measurement of operational performance. In another study different indicators including speed of delivery and cost of transportation was determined for the operational performance measurement. Other operational performance measures include flexibility, quality, product flow and reduction order variance (Vanichchinchai, 2014; Frohlich \& Westbrook, 2001). In this study, operational performance is measured using flexibility, speed, cost and quality because they are widely used in the measurement of operational performance in previous studies (Vanichchinchai, 2014; Maestrini et al., 2017).

Flexibility is referred to the degree to which organisations are able to respond fast to the market changes such as volumes, schedules and product mix (Rosenzweig, Roth \& Dean Jr, 2002). Speed performance is referred to the time it takes for product or service to be delivered to the consumer (Gimenez, Vaart \& Donk, 2011). The lesser the time the better the performance. Quality performance refers to the degree to which a product or services conforms to standards and customer requirements. Cost refers to the total amount of the money it takes to get a specific activity completed within the supply chain (Bowersox, Closs \& Cooper, 2007). Cost performance in supply chain refers to the reduction in inventories, resource maximization and elimination of the non-added-value activities with the goal of reducing the overall cost of operations.

\subsection{Supply Chain Internal Integration and Operational Performance}

The relationship between supply chain integration and the performance of manufacturing firms in Kenya was assessed by Njagi and Muli, (2020). The study used a mixed method approach and the selected sample size was 85 employees. A stratified sampling technique was used to determine the specific sample size of each stratum of the study. Data were obtained through a questionnaire. The data was analyzed using regression analysis. The findings of the study revealed that technology integration, internal operations integration, and customer integration significantly influence the performance of manufacturing firms in Kenya. This gives the indication that increases in internal integration, technology integration and customer integration lead to increases in the performance of manufacturing firms in Kenya and vice versa. However, the results revealed that supplier integration had a negative influence on performance, giving the implication that supplier integration is not able to positively influence performance of manufacturing firms.

In another study Som, Cobblah and Anyigba (2019) investigated the effect of the SCI on the performance of supply chains in Ghana's manufacturing companies. The dimensions of SCI examined in this study included operational, relational and informational integration. The research approach used was quantitative and 1500 employees were used as the sample size for the study. The findings of the study revealed that whiles both informational and operational integration produced a positive impact on the performance of the supply chain that of relational integration was negative. The results therefore implies that increases in informational and operational integration brings about increases in the supply chain performance of manufacturing firms. That notwithstanding, relational integration is not positively linked to supply chain performance of manufacturing firms. 
In a similar study, the extent to which the operational performance of hospitals in Kenya was impacted by SCI was examined by Annea and Julianab (2019) using a quantitative research approach. A sample size of 164 employees was used. The results of the study revealed that internal integration, customer integration and supplier integration all had a significant positive effect on the operational performance of the hospitals. This gives the indication that, increases in internal, supplier and customer integration leads to increases in operational performance of the hospitals and vice versa.

In a study, Osei and Kagniciogu (2018) assessed the extent to which business and operational performance are impacted by SCI in Turkey's food industry. The study adopted a quantitative research approach, and 216 firms were determined as the sample size. Specifically, the study assessed the effect of internal, customer and supplier integration on the operation and business performance. The findings of the study revealed that all three dimensions of SCI had a significant positive effect on operational and business performance. The implication is that, increases in the three dimensions of supply chain integration (supplier, customer, internal) brings about improvements in the operational and business performance of Turkey's food industry.

Uwamahoro (2018) also examined the impact of the SCI on the performance of the manufacturing firms in Rwanda. A sample size of 258 employees was used for the study. The findings revealed that internal integration, supplier integration and customer integration all impacted on operational and firm performance although internal integration and customer integration predicted the strongest relationship with performance. The findings is an indication that, improvements in internal, supplier and customer integration has positive implications on the operational performance of manufacturing firms in Rwanda.

In another study, $\mathrm{Ni}$ (2015) explored the moderating effect of IT competence (IT human resource and IT strategy) on the relationship that exists between SCI and operational performance. The study selected 191 manufacturers from 10 countries and the data were analyzed using hierarchical linear regression. The findings of the study revealed that SCI practices, including internal integration, process integration and product integration were influenced by IT competence. The study further established that the operational performance of IT strategy was influenced by the internal integration, process integration and product integration. The findings of the study further revealed that IT competence moderated the relationship between SCI and operational performance.

Atnafu and Hussen (2015) assessed 35 Ethiopian chemical manufacturing firms and the influence of SCI on their operational performance. The study used a quantitative research approach for the study and the findings of the study revealed that internal integration, supplier integration and customer integration demonstrated a significant positive relationship with operational performance. This finding therefore indicates that improvements in supplier, internal and customer integrations brings about improvement sin operational performance among chemical manufacturing firms in Ethiopia.

El-Tamimi (2015) in a related study investigated the influence of SCI on the operational performance of Jordanian Pharmaceutical companies. Using a sample size of 235 the study indicated a positive significant relationship between SCI and operational performance. The findings therefore implies that increases in SCI leads to increases in operational performance among Jordanian Pharmaceutical firms.

Huo, Qi, Wang and Zhao (2014) examined the extent to which the relation between SCI and operation performance in Chinese manufacturing companies is moderated by competitive strategy. Using a quantitative research approach, the study determined a sample size of 604 manufacturing companies. Using hierarchical linear regression, the findings of the study revealed that the SCI practices that comprise of internal process and product integration were influenced by competitive strategies. The study further confirmed that the relationship between SCI and operational performance was not moderated by competitive strategies. 
Based on the literature review, the following are hypothesized:
H1: A significant positive relationship exist between internal integration and operational performance.
H2: A significant positive relationship exist between internal integration and supplier integration.
H3: There is a significant positive relationship between internal integration and customer integration.
H4: There is a significant positive relationship between supplier integration and operational performance.
H5: There is a significant positive relationship between customer integration and operational performance.
H6: Supplier integration mediates the relationship between internal integration and operational performance.
H7: Customer integration mediates the relationship between internal integration and operational performance.

\section{Methodology}

A quantitative survey research design was adopted. According to Saunders, Lewis and Thornhill (2016), the quantitative survey research design requires the collection of data from a large number of units that will be analyzed statistically to make inferences from the population. As a result of the quantitative survey research design, a total of thirty (30) manufacturing firms in the Greater Accra Region of Ghana were sampled for the study using the cluster sampling technique. The use of the cluster sampling was justified on the premise that the manufacturing firms sampled were clustered within the Tema Enclave, which is a geographical location noted for both local and foreign manufacturing firm operations in Ghana. The study targeted the procurement, accounts and administration officers of these manufacturing firms. The total population of employees from the procurement, accounts and administration officers in the thirty (30) manufacturing firms was one thousand, eight hundred $(1,800)$. Using the Kregcie and Morgan (1970) table for sample size determination, the appropriate sample size of three hundred and seventeen (317) was chosen for the study. Employees selected to participate in the study were chosen using the convenience sampling technique as their availability and willingness to participate in the study formed the basis for their inclusion in the study. The convenience sampling technique was also appropriate since it strengthened adherence to the ethical standard of informed consent during the data collection process. Questionnaires served as the data collection instrument.

Supplier and internal integration were measured using a five-point likert scale with the following options: $1=$ strongly Disagree, 2=Disagree, 3=Neutral, 4=Agree and 5=Strongly Agree. The supplier and internal integration questionnaire was developed by Flynn et al. (2010). Customer integration was measured using a five-point scale adopted from Li et al. (2015). Operational performance was measured using a five-point scale adopted from Wiengarten, Pagell, Ahmed and Gimenez (2014). Validity and reliability tests were conducted to questionnaire using IBM AMOS

\section{Results}

Results from Table 1 indicate that most of the respondents (69.7\%) were males while females constituted 30.7\%. Regarding age distribution of respondents, $39.1 \%$ were between the ages of $25-35$ years; $30.9 \%$ were between the ages of $36-45$ years; $19.6 \%$ were less than 25 years while $10.4 \%$ were more than 45 years. The results showed that most employees have worked in manufacturing firms for 5-10 years $(60.6 \%) ; 27.8 \%$ have worked in manufacturing firms for less than 5 years while $11.6 \%$ have worked in manufacturing firms for more than 10 years. In terms of educational level, it was revealed that most employees have attained their first degree (65\%), 23.9\% have attained their diploma/HND and $11.1 \%$ have attained their masters/postgraduate. 


\begin{tabular}{|c|c|c|}
\hline Gender & Frequency & Percentage $(\%)$ \\
\hline Male & 221 & 69.7 \\
\hline Female & 96 & 30.3 \\
\hline Total & 317 & 100 \\
\hline Age & Frequency & Percentage $(\%)$ \\
\hline Less than 25 years & 62 & 19.6 \\
\hline $25-35$ years & 124 & 39.1 \\
\hline $36-45$ years & 98 & 30.9 \\
\hline More than 45 years & 33 & 10.4 \\
\hline Total & 317 & 100 \\
\hline Tenure & Frequency & Percentage $(\%)$ \\
\hline Less than 5 years & 88 & 27.8 \\
\hline $5-10$ years & 192 & 60.6 \\
\hline 10 years and above & 37 & 11.6 \\
\hline Total & 317 & 100 \\
\hline Educational Level & Frequency & Percentage $(\%)$ \\
\hline Diploma/HND & 76 & 23.9 \\
\hline First Degree & 206 & 65.0 \\
\hline Masters/Postgraduate & 35 & 11.1 \\
\hline Total & 317 & 100 \\
\hline
\end{tabular}

Table 1. Demographic data of respondents

\subsection{Validity/Reliability Statistics}

A number of preliminary analyses were conducted. Cronbach's alpha was assessed to check the internal consistency of the scale. The Cronbach's alpha of the scales is presented in Table 2. Each of the scales recorded high reliability of above 0.700 (Pallant, 2020). Due to few contextually and theoretically relevant alterations were made to some of the scale items, it was necessary to conduct an exploratory factor analysis (EFA). The EFA demonstrated a Kaiser-Meyer-Olkin (KMO) value of 0.793 and the Bartlett's Test of Sphericity showed a p-value of <.0001. A confirmatory factor analysis (CFA) was done to confirm and examine how the items held together on the various variables and dimensions. The data were analysed in IBM SPSS Statistic version 26 and IBM AMOS version 23.

\begin{tabular}{|c|c|c|c|c|c|}
\hline Variable & $\begin{array}{c}\text { Sub } \\
\text { Variable }\end{array}$ & $\begin{array}{l}\text { Measurement } \\
\text { Index }\end{array}$ & Scale Item & $\begin{array}{l}\text { Factor } \\
\text { Loading }\end{array}$ & $\begin{array}{l}\text { Cronbach's } \\
\text { Alpha }\end{array}$ \\
\hline \multicolumn{5}{|c|}{ Internal Integration } & \multirow[t]{10}{*}{0.918} \\
\hline & & IN1 & $\begin{array}{l}\text { Our organisation engages all departments when } \\
\text { strategic plans are being prepared }\end{array}$ & 0.824 & \\
\hline & & IN2 & $\begin{array}{l}\text { Our organisation uses of material requirement } \\
\text { planning to manage and control production }\end{array}$ & 0.826 & \\
\hline & & IN3 & Information sharing within the organisation is effective & 0.587 & \\
\hline & & IN4 & $\begin{array}{l}\text { There is regular training of employees to enhance their } \\
\text { competencies }\end{array}$ & 0.478 & \\
\hline & & IN5 & $\begin{array}{l}\text { Our organisation organizes regular meeting } \\
\text { departmental heads so as to effectively coordinate } \\
\text { Works }\end{array}$ & 0.829 & \\
\hline & & IN6 & $\begin{array}{l}\text { Our organisation regularly includes employees in } \\
\text { regular meetings }\end{array}$ & 0.847 & \\
\hline & & IN7 & $\begin{array}{l}\text { Our organisation gives room for employees be part of } \\
\text { solving of problems and resolving of conflicts }\end{array}$ & 0.731 & \\
\hline & & IN8 & $\begin{array}{l}\text { The production process of our organisation involves } \\
\text { all departments of the organisation }\end{array}$ & 0.761 & \\
\hline & & IN9 & $\begin{array}{l}\text { Our organisation has a number of teams which work } \\
\text { together }\end{array}$ & 0.812 & \\
\hline
\end{tabular}




\begin{tabular}{|c|c|c|c|c|c|}
\hline Variable & $\begin{array}{l}\text { Sub } \\
\text { Variable }\end{array}$ & $\begin{array}{l}\text { Measurement } \\
\text { Index }\end{array}$ & Scale Item & $\begin{array}{l}\text { Factor } \\
\text { Loading }\end{array}$ & $\begin{array}{l}\text { Cronbach's } \\
\text { Alpha }\end{array}$ \\
\hline \multicolumn{5}{|c|}{ External Integration } & 0.917 \\
\hline & \multicolumn{4}{|c|}{ Supplier Integration } & 0.884 \\
\hline & & SI1 & $\begin{array}{l}\text { There is electronic information sharing with suppliers } \\
\text { from my organisation }\end{array}$ & 0.748 & \\
\hline & & $\mathrm{SI} 3$ & $\begin{array}{l}\text { Our contracts with suppliers clearly spell out } \\
\text { specification, quantities, cost and delivery time for all } \\
\text { supplies }\end{array}$ & 0.715 & \\
\hline & & $\mathrm{SI} 5$ & $\begin{array}{l}\text { Our organisation accepts input of suppliers in the } \\
\text { design of products }\end{array}$ & 0.650 & \\
\hline & & $\mathrm{SI} 7$ & $\begin{array}{l}\text { Our organisation together with our suppliers undertake } \\
\text { training together }\end{array}$ & 0.695 & \\
\hline & & SI8 & $\begin{array}{l}\text { Our organisation controls inventory by connecting } \\
\text { electronically with our suppliers }\end{array}$ & 0.818 & \\
\hline & & SI9 & $\begin{array}{l}\text { There is an ongoing deliberation on how the } \\
\text { relationship between our organisation and suppliers } \\
\text { can be strengthened }\end{array}$ & 0.761 & \\
\hline & & SI10 & $\begin{array}{l}\text { Our organisation and suppliers regularly have } \\
\text { awareness programs so as to develop the business }\end{array}$ & 0.682 & \\
\hline & \multicolumn{4}{|c|}{ Customer Integration } & 0.850 \\
\hline & & CI1 & $\begin{array}{l}\text { The main goal of our organisation to satisfy the } \\
\text { customer }\end{array}$ & 0.531 & \\
\hline & & $\mathrm{CI} 3$ & $\begin{array}{l}\text { Our organisation a customer service department } \\
\text { attends to customer needs }\end{array}$ & 0.702 & \\
\hline & & $\mathrm{CI} 4$ & $\begin{array}{l}\text { Our organisation has mechanism that ensures orders } \\
\text { from our customer are received in real time }\end{array}$ & 0.554 & \\
\hline & & CI5 & $\begin{array}{l}\text { Our organisation has a customer relationship } \\
\text { management system in place }\end{array}$ & 0.641 & \\
\hline & & CI8 & $\begin{array}{l}\text { Our organisation ensures that all customer complaints } \\
\text { and speedily and appropriately dealt with }\end{array}$ & 0.831 & \\
\hline & & CI9 & $\begin{array}{l}\text { Our organisation involves customer in the } \\
\text { development of marketing programs }\end{array}$ & 0.536 & \\
\hline & & CI10 & $\begin{array}{l}\text { Our customers are engaged during the design of the } \\
\text { organisation products and services }\end{array}$ & 0.743 & \\
\hline \multicolumn{5}{|c|}{ Operational Performance } & 0.865 \\
\hline & \multicolumn{4}{|c|}{ Time } & 0.815 \\
\hline & & OPT1 & $\begin{array}{l}\text { Our organisation is committed to provide fast service } \\
\text { to its customers }\end{array}$ & 0.540 & \\
\hline & & OPT2 & $\begin{array}{l}\text { Our organisation ensures product and service are } \\
\text { delivered on time to customer }\end{array}$ & 0.784 & \\
\hline & & OPT3 & Our supplier delivers supplies on time & 0.706 & \\
\hline & & OPT4 & $\begin{array}{l}\text { The company reserves the minimum limit of stock } \\
\text { which could continue of work in the case of raw } \\
\text { material delay }\end{array}$ & 0.632 & \\
\hline & & OPT5 & $\begin{array}{l}\text { The company bears the differences in transportation } \\
\text { costs in order to meet the deadlines of supplying } \\
\text { orders to customers }\end{array}$ & 0.795 & \\
\hline
\end{tabular}




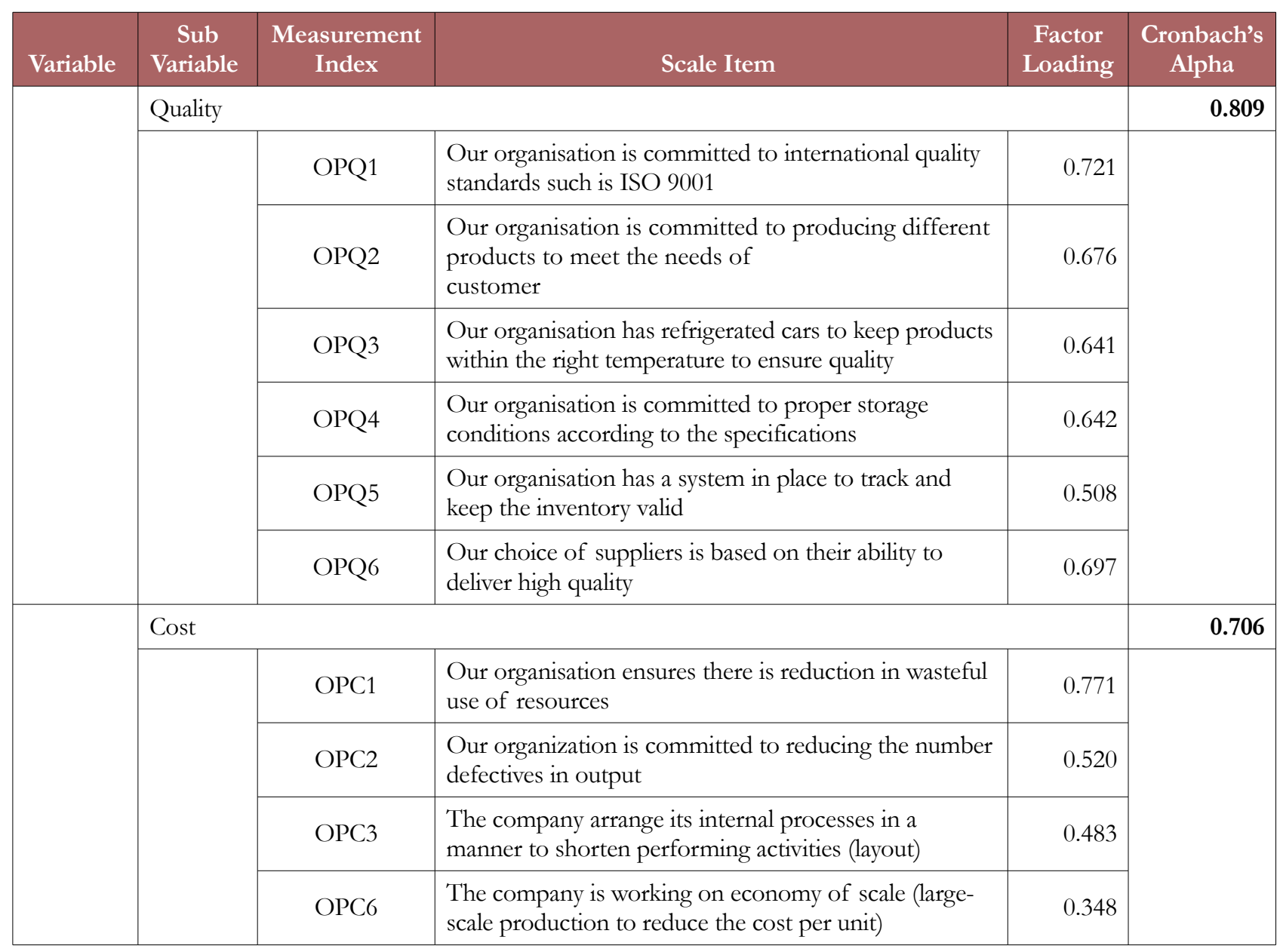

Table 2. Validity and Reliability Statistics

\subsection{Confirmatory Factor Analysis}

The CFA was conducted in AMOS. The researchers developed a CFA model and covaried all variables. The operational performance scale was structured in a second order. The items were correlated and then factor loadings were checked. Items that had low factor loadings were removed and only items with loadings above 0.500 were included. The CFA had a good fit with the data. The following model fit indices were obtained for the CFA: Chi Square $\left(\chi^{2}\right)=624.660$, $p$-value $(p)=0.001$, Chi square/Degree of freedom $\left(\chi^{2} / \mathrm{df}\right)=2.30$; root mean square error of approximation $($ RMSEA $)=0.043$, Root Mean Square Residual $(\mathrm{RMR})=0.018$, standardised Root Mean Square Residual $(\mathrm{SRMR})=0.045$, comparative fit index $(\mathrm{CFI})=0.971$, Normed Fit Index $(\mathrm{NFI})=0.961$, Goodness of Fit $(\mathrm{GFI})=0.961$. Each of the regression weights of each item to the variables were adequately significant $(\mathrm{p}<.05)$.

The construct reliability, and convergent and discriminant validity were obtained after pasting the standardised regression and correlations in the statswiki validity calculator (Gaskin, 2021). The results are presented in Table 3. All the average variance extracted (AVE) values were above 0.50 and construct reliabilities greater than 0.70 . Accordingly, the AVE values were also greater than the square of their correlations, which supports discriminant validity. Common method bias (CMB) and multicollinearity tests were also assessed to avoid being misled by inappropriate data. The $\mathrm{CMB}$ value was .549 the squared of this value is $0.256(25.6 \%)$, which means that CMB was not violated. 


\begin{tabular}{|l|r|r|r|r|r|r|r|}
\hline & \multicolumn{1}{c|}{ CR } & \multicolumn{1}{c|}{ AVE } & \multicolumn{1}{c|}{ MSV } & \multicolumn{1}{c|}{ IN } & \multicolumn{1}{c|}{ CI } & SI & OP \\
\hline Internal Integration (IN) & 0.820 & 0.604 & 0.166 & $\mathbf{0 . 7 7 7}$ & & & \\
\hline Customer Integration (CI) & 0.806 & 0.511 & 0.321 & 0.303 & $\mathbf{0 . 7 1 5}$ & & \\
\hline Supplier Integration (SI) & 0.860 & 0.673 & 0.321 & 0.205 & 0.567 & $\mathbf{0 . 8 2 0}$ & \\
\hline Operational Performance (OP) & 0.753 & 0.513 & 0.177 & 0.017 & 0.255 & 0.421 & $\mathbf{0 . 7 1 6}$ \\
\hline
\end{tabular}

CR: Construct Reliability; AVE: Average Variance Extracted; MSV: Maximum Shared Variance.

Table 3. CFA results

\subsection{Structural Equation Model Results}

Structural equation modelling was conducted in IBM AMOS version 23 to assess the relationships in the a priori framework developed. The structural model presented in Figure 1 shows the strengths of the relationships hypothesized.

The structural model obtained the following indices: $\chi^{2}=124.660, \mathrm{p}=0.012, \chi^{2} / \mathrm{df}=2.13$; 0.041, Root Mean Square Residual $(\mathrm{RMR})=0.019, \mathrm{SRMR}=0.042, \mathrm{CFI}=0.964, \mathrm{NFI}=0.951, \mathrm{GFI}=0.973$. The model showed support for all hypotheses except for the direct relationship between internal integration and operational performance $(\beta=-0.440, \mathrm{p}=0.163, \mathrm{R} 2=0.70)$. Therefore, the first hypothesis was unsupported. This suggests that internal integration does not lead to operational performance. Hypothesis 2 was however, supported. The study found a strong statistically significant relationship between internal integration and supplier integration $(\beta=0.975, \mathrm{p}<0.001, \mathrm{R} 2=0.95)$. Hypothesis 3 was also supported in that, internal integration was found to have a strong significant effect on customer integration $(\beta=0.850, \mathrm{p}<0.001, \mathrm{R} 2=0.72)$. The first three hypotheses thus suggest that internal integration had a significant impact on external integration but not operational performance. Hypothesis 4 was also supported. Supplier integration had a significant impact on operational performance $(\beta=0.614, \mathrm{p}<0.05, \mathrm{R} 2=0.70)$. Hypothesis 5 was also supported, customer integration recorded a strong effect on operational performance $(\beta=0.686, \mathrm{p}<0.001, \mathrm{R} 2=0.70)$.

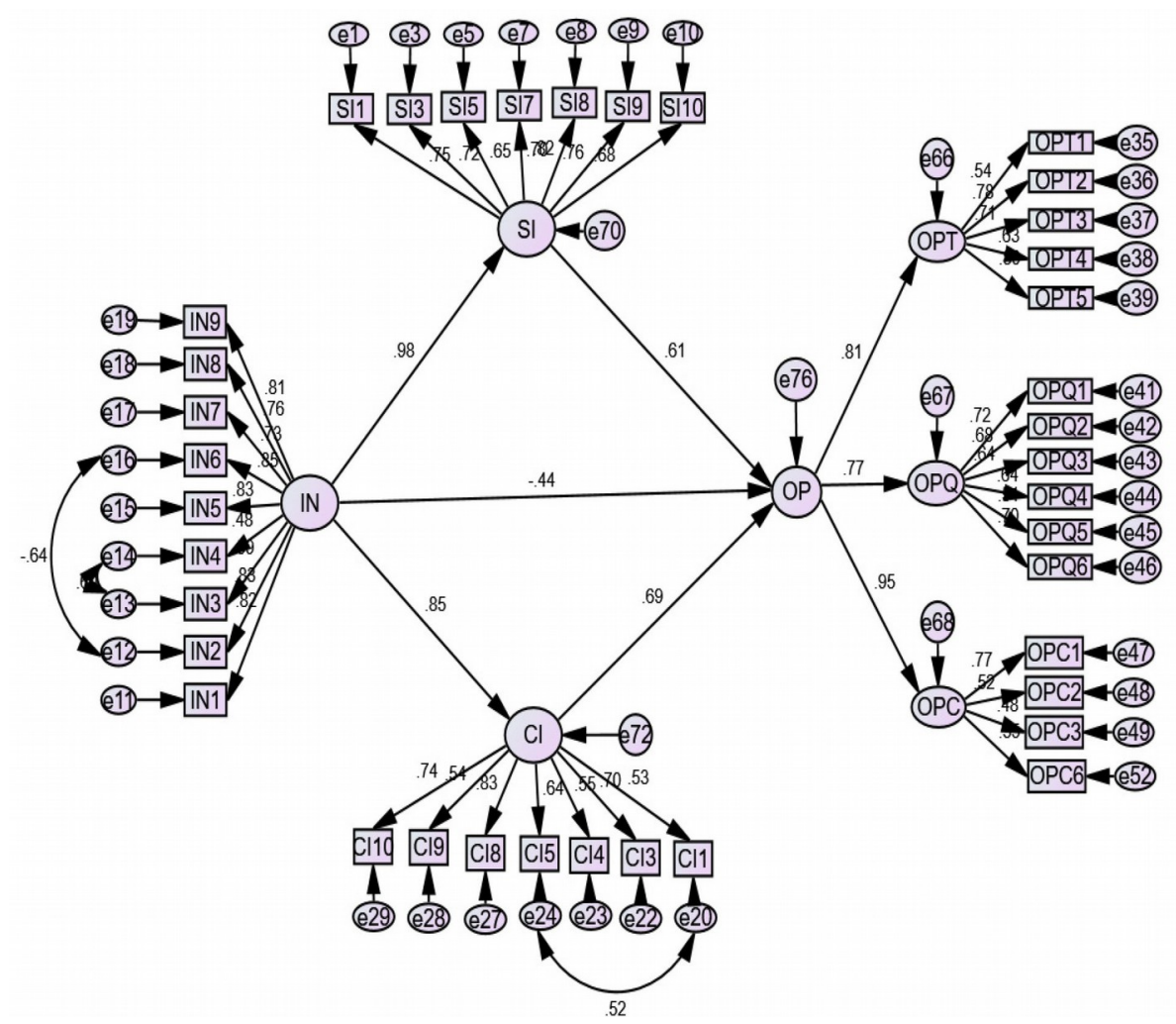

Figure 1. Structural model of the relationship between supply chain integration and operational performance 
The first five sets of hypotheses open an interesting page in SCI research. Whereas internal integration has no significant impact on operational performance, it does have a significant impact on external integration (i.e., supplier and customer integration) and external integration had a significant effect on operational performance. This provides an even more justification for the assessment of the mediation effects of the external integration variables between internal integration and operational performance.

\begin{tabular}{|c|l|r|r|r|r|}
\hline Hypotheses & \multicolumn{1}{|c|}{ Path } & $\begin{array}{c}\text { Standardised } \\
\text { Estimate }(\beta)\end{array}$ & T-value & P-Value & \multicolumn{1}{c|}{ R2 } \\
\hline H1 & Internal Integration $\rightarrow$ Operational Performance & -0.440 & -1.395 & 0.163 & 0.70 \\
\hline H2 & Internal Integration $\rightarrow$ Supplier Integration & 0.975 & 21.989 & $* * *$ & 0.95 \\
\hline H3 & Internal Integration $\rightarrow$ Customer Integration & 0.850 & 13.263 & $* * *$ & 0.72 \\
\hline H4 & Supplier Integration $\rightarrow$ Operational Performance & 0.614 & 2.015 & 0.044 & 0.70 \\
\hline H5 & Customer Integration $\rightarrow$ Operational Performance & 0.686 & 7.002 & $* * *$ & 0.70 \\
\hline
\end{tabular}

Table 4. Path analysis

\subsection{Mediation Analysis}

Hypotheses 6 and 7 were tested through mediation analyses. To do this, the researchers followed the procedure by Collier (2020) and named the independent paths. Then, a new estimate was created which enabled the testing of the individual indirect effects of the two mediators. Table 5 shows the mediation effect for supplier integration and customer integration.

The indirect effect of internal integration through supplier integration to operational performance $(\beta=0.598$, $\mathrm{p}<0.001)$ was found to be significant. The bootstrapped two tailed significant showed a $\mathrm{p}$-value less than 0.001 ( $\mathrm{p}<0.001)$. Hence, hypothesis 6 was supported.

Hypothesis 7 was also analysed in mediation analysis. The result suggests that customer integration significantly mediates the relationship between internal integration and operational performance. The indirect effect of internal integration through customer integration to operational performance $(\beta=0.587, \mathrm{p}<0.001)$ was found to be significant after checking the bootstrapped two tailed significant showed a $\mathrm{p}$-value less than $0.001(\mathrm{p}<0.001)$. Hence, hypothesis 7 was supported.

\begin{tabular}{|c|r|c|c|}
\hline Path & Standardized Path Coefficient $\beta$ & P value & \multicolumn{1}{|c|}{$\mathbf{R}^{2}$} \\
\hline $\mathrm{IN} \rightarrow \mathrm{SI} \rightarrow$ OP & 0.598 & $* * *$ & 0.70 \\
\hline $\mathrm{IN} \rightarrow \mathrm{CI} \rightarrow$ OP & 0.587 & $* * *$ & 0.70 \\
\hline
\end{tabular}

Table 5. Mediation of Supplier and Customer Integration

\section{Discussion}

Comparing the results to literature, the study found that the direct effect of internal integration and its impact on operational performance was not consistent with literature. However, other direct effects among the constructs were consistent with literature. The study found that internal integration does not contribute to operational performance among the selected manufacturing firms. The findings on internal integration and its effect on operational performance was not consistent with literature. This is because, previous studies have shown that significant positive relationships exist between internal integration and operational performance (Annea \& Julianab, 2019; Osei \& Kagniciogu, 2018). The findings which showed that customer integration and supplier integration impacts positively on operational performance among manufacturing firms was consistent with relevant literature (Annea \& Julianab, 2019; Osei \& Kagniciogu, 2018; Uwamahoro, 2018). The results of the study which showed 
that internal integration contributes positively to supplier and customer integration was also consistent with literature (Kim et al, 2013).

The results of the study was also unique as none of the studies reviewed assessed the indirect/mediated effects of customer and supplier integration on the relationship between internal integration and operational performance among manufacturing firms. The results did show that supplier integration and customer integration both significantly mediated the relationship between internal integration and operational performance among the manufacturing firms. The implication is that, the integration of internal structures and departmental units within manufacturing firms cannot independently lead to operational performance. Thus, manufacturing firms can only achieve operational performance if the integration of their internal structures and departmental units is strategically linked to both supplier and customer integration. The study therefore recommends that manufacturing firms that seek to achieve competitive advantage must link their internal integration to customer and supplier integration in order to be able to meet and exceed the expectations of their customers and achieve high levels of profitability.

\section{Conclusion}

This study found that internal integration does not independently lead to operational performance, unless it is connected to supplier and customer integration. The study therefore concludes that management of manufacturing firms must pay equal attention to internal, supplier and customer integration as the connections among these three dimensions of supply chain integration enhance operational performance. The study also concludes that the connections between internal integration, supplier integration and customer integration must be strengthened by manufacturing firms in order to achieve operational performance.

The study therefore provides the following recommendations. Firstly, it is important for management of manufacturing firms to strengthen their internal supply chain activities in order to enhance proper coordination among different departmental units so as to build a unique internal supply chain climate that can enhance operational performance. The study also recommends the need for management of manufacturing firms to make use of ICT tools such as Enterprise Resource Planning (ERP) to link their internal supply chain to their external supply chain actors such as suppliers and customers in order to enhance visibility in their supply chain activities and achieve optimum operational performance in real time.

\section{Declaration of Conflicting Interests}

The authors declared no potential conflicts of interest with respect to the research, authorship, and/or publication of this article.

\section{Funding}

This work is based on research supported by the Collaborative Program in Additive Manufacturing (Contract NoCSIR-NLC-CPAM-18-MOA-CUT-01).

\section{References}

Annea M., \& Julianab, N. (2019) Supply chain integration and operational performance of Kenya's public health sector. International Journal of Research in Business and Social Science, 8(5), 1-10. https://doi.org/10.20525/ijrbs.v8i5.472

Ataseven, C., \& Nair, A. (2017). Assessment of supply chain integration and performance relationships: A meta-analytic investigation of the literature. International Journal of Production Economics, 185, 252-265. https://doi.org/10.1016/j.ijpe.2017.01.007

Atnafu, D., \& Hussen, O.S. (2015). The Effect of Supply Chain Integration on Operational Performance: The Case of Chemical Industry in Ethiopia. European Journal of Business and Management, 7(28), 24-29.

Azim, M., Ahmed, H., \& Khan, S.A. (2015). Operational Performance and Profitability: An Empirical Study on the Bangladeshi Ceramic Companies. International Journal of Entrepreneurship and Development Studies, 3(1), 63-73.

https://doi.org/10.5296/ijafr.v5i1.6803 
Bowersox, D., Closs, D.J., \& Copper, M.B. (2007). Supply Chain Logistics Management: Operational, Financial, and Social Performance. McGraw-Hill, New York.

Collier, J.E. (2020). Applied structural equation modeling using AMOS: Basic to advanced techniques. London: Routledge.

Dzogbewu, T.C. (2010). The outsourcing of logistical activities: The case of Guinness Ghana Breweries Limited. Masters thesis. Blekinge Institute of Technology, School of Management.

Ebrahimi, S.M. (2015). Examining the Impact of Supply Chain Integration on Organization Structure and Operational Performance in Oil and Gas Supply Chains: A Contingency Approach. University of Sheffield, UK.

Echtelt, F., Wynstra, F., Weele, A., \& Duysters, G. (2008). Managing Supplier Involvement in New Product Development: A Multiple-Case Study. The Journal of Product Innovation Management, 25(2), 180-201. https://doi.org/10.1111/j.1540-5885.2008.00293.x

El-Tamimi, H.S. (2015). The Impact of Supply Chain Integration on Operational Performance at Jordanian Pharmaceutical Manufacturing Organizations (Doctoral dissertation, PhD Dissertation, Management Department, Middle East University).

Errassafi, M., Abbar, H., \& Benabbou, Z. (2019). The mediating effect of internal integration on the relationship between supply chain integration and operational performance: Evidence from Moroccan Manufacturing Companies. Journal of Industrial Engineering and Management, 12 (2), 254-273. https://doi.org/10.3926/jiem.2794

Flynn B.B., Huo B., \& Zhao X. (2010). The impact of supply chain integration on performance: A contingency and configuration approach. Journal of Operations Management, 28, 58-71. https://doi.org/10.1016/j.jom.2009.06.001

Fianko, S.K., Afrifa Jnr, S., \& Dzogbewu, T.C. (2020). Does the interpersonal dimension of Goleman's emotional intelligence model predict effective leadership? African Journal of Business and Economic Research, 15(4), 221-245. https://doi.org/10.31920/1750-4562/2020/v15n4a10

Frohlich, M.T., \& Westbrook, R. (2001). Arcs of integration: an international study of supply chain strategies. Journal of Operations Management, 19 (2), 185-200. https://doi.org/10.1016/S0272-6963(00)00055-3

Gaskin, J. (2021). Validity master, Stats Tools Package. Retrieved from: http://statwiki.kolobreations.com

Georgise, F.B., Thoben, K., \& Seifert, M. (2014). Supply Chain Integration in the manufacturing firms in developing countries: A case study of Ethiopia. Journal of Industrial Engineering. https://doi.org/10.1155/2014/251982

Gimenez, C., Vaart, T.V.D., \& Donk, D.P.V. (2011). Supply chain integration and performance: the moderating effect of supply complexity. Supply Chain Management: An International Journal, 17(6), 596-610. https://doi.org/10.1108/01443571211226506

Han, J., Lu, H., Trienekens, J.H., \& Omta, S.W.F. (2013). The impact of supply chain integration on firm performance in the pork processing industry in China. Chinese Management Studies, 7(2), 230-252. https://doi.org/10.1108/CMS-Jun-2011-0034

Huo, B. (2012). The impact of supply chain integration on company performance: an organizational capability perspective. Supply Chain Management: An International Journal, 17 (6), 596-610. https://doi.org/10.1108/13598541211269210

Huo, B., Qi, Y., Wang, Z., \& Zhao, X. (2014). The impact of supply chain integration on firm performance: The moderating role of competitive strategy. Supply Chain Management: An International Journal, 19(4), 369-384. https://doi.org/10.1108/SCM-03-2013-0096

Jacobs, M.A., Yu, W., \& Chavez, R. (2016). The effect of internal communication and employee satisfaction on supply chain integration. International Journal of Production Economics, 171, 60-70.

https://doi.org/10.1016/j.ijpe.2015.10.015

Kahn, K.B., \& Mentzer, J.T. (1996). Logistics and interdepartmental integration. International Journal of Physical Distribution \& Logistics Management, 26 (8), 6-14. https://doi.org/10.1108/09600039610182753 
Kim, D.Y. (2013). Relationship between supply chain integration and performance. Operations Management Research, 6(1-2), 74-90

Krajewski, L., Ritzman, L., \& Malhotra, M. (2013). Operations Management, Processes and Supply chains. 10th ed. Upper Saddle River, New Jersey: Pearson Education Limited.

Lee, C.W., Kwon, I.G., \& Severance, D. (2007). Relationship between Supply Chain Performance and Degree of Linkage among Supplier. Internal Integration and Customer. Supply Chain Management International Journal, 12, 444-452. https://doi.org/10.1108/13598540710826371

Leuschner, R., Rogers, D.S., \& Charvet, F.F. (2013). A Meta-Analysis of Supply Chain Integration and Firm Performance. Journal of Supply Chain Management, 49(2), 34-57. https://doi.org/10.1111/jscm.12013

Li, G., Fan, H., Lee, P K. C., \& Cheng, T.C.E. (2015). Joint supply chain risk management: An agency and collaboration perspective. International Journal of Production Economics, 164, 83-94.

https://doi.org/10.1016/j.ijpe.2015.02.021

Maestrini, V., Luzzini, D., Maccarrone, P., \& Caniato, F. (2017). Supply chain performance measurement systems: A systematic review and research agenda. International Journal of Production Economics, 183, 299-315.

https://doi.org/10.1016/j.ijpe.2016.11.005

Ni, L. (2015). The Impact of Supply Chain Integration on Operation Performance: The Moderating Role of IT Competence. Management Science and Engineering, 9(4), 40-45.

Njagi J.M., \& Muli, S.M. (2020). Influence of Supply Chain Integration Practices on the Performance of Manufacturing Firms in Kenya a Case of Kenya Breweries Limited. International Journal of Business and Social Research, 10(1), 35-57.

Njagi, M.M., \& Ogutu, M. (2014). Role of supply chain integration on supply chain performance in Kenyan State Corporations. International Journal of Current Business and Social Sciences, 1(2), 188-204.

Osei, M.B., \& Kagniciogu, C.H. (2018). The impact of supply chain integration on firms' business and operational performance at the food retailsector/industry. Journal of Management, Marketing and Logistics, 5(1),18-30. https://doi.org/10.17261/Pressacademia.2018.805

Pallant, J. (2020). SPSS survival manual: A step by step guide to data analysis using IBM SPSS. London: Routledge.

Perdana, Y.R., Ciptono, W.S., \& Setiawan, K. (2018). The Relationship between Internal and External Integration of Supply Chain and Operational Performance. Proceedings of the International Conference on Industrial Engineering and Operations Management. Paris, France.

Rosenzweig, E.D., Roth, A.V., \& Dean Jr, J.W. (2002). The influence of an integration strategy on competitive capabilities and business performance: An exploratory study of consumer products manufacturers. Journal of Operations Management, 21, 437-456. https:/ / doi.org/10.1016/S0272-6963(03)00037-8

Saunders, M., Lewis, P., \& Thornhill, A. (2016). Research methods for business students (Seventh). Newa York: Pearson Education

Soliman, F. (2015). Does the Cloud System Drive Supply Chain Sustainability?. In Cloud systems in supply chains (224245). London: Palgrave Macmillan.

Som, J.O., Cobblah, C., \& Anyigba, H. (2019). The effect of supply chain integration on supply chain performance. Proceedings of the Ninth International Conference on Engaged Management Scholarship (2019). https://doi.org/10.2139/ssrn.3468798

Somjai, S., Girdwichai, L., \& Jermsittiparsert, K. (2019). The mediating role of operational performance and internal integration of supply chain in the relationship between interplant coordination and external integration. Journal of Human Sport and Exercise, 14(5), 2187-2201. https:/ / doi.org/10.14198/jhse.2019.14.Proc5.38

Sousa, R. (2003). Linking quality management to manufacturing strategy: an empirical Investigation of customer focus practices. Journal of Operations Management, 21(1), 1-18. https:/ / doi.org/10.1016/S0272-6963(02)00055-4 
Tan, K.C., Kannan, V.R., \& Handfield, R.B. (1998). Supply chain management: supplier performance and firm performance. International Journal of Purchasing and Materials Management, 34(3), 2-9. https://doi.org/10.1111/j.1745493X.1998.tb00042.x

Tarifa-Fernandez, J., \& De Burgos-Jimenez, J. (2017). Supply chain integration and performance relationship: a moderating effects review. International Journal of Logistics Management, 28(4),1243-1271.

https://doi.org/10.1108/IJLM-02-2016-0043

Tavana, S.M., Shabani, A., \& Singh, R. (2019). The impact of interwoven integration practices on supply chain value addition and firm performance. Journal of Industrial Engineering International, 15(1), 39-51.

https://doi.org/10.1007/s40092-019-0316-8

Uwamahoro, A. (2018). Effects of supply chain integration on performance: An analysis of manufacturing firms in Rwanda. East Africa Research Papers in Business, Entrepreneurship and Management, 3, 3-20.

Vanichchinchai, A. (2014). Supply chain management, supply performance and total quality management. International Journal of Organizational Analysis, 22(2), 126-148. https://doi.org/10.1108/IJOA-08-2011-0500

Wang, S., Chang, S., \& Wang, R. (2009). Assessment of supplier performance based on product- development strategy by applying multi-granularity linguistic term sets. Omega, 37(1), 215-226.

https://doi.org/10.1016/j.omega.2006.10.003

Wasti, S., \& Jeffrey, L. (1999). Collaborating with Suppliers in Product Development: A U.S. and Japan Comparative Study. IEEE Transactions on Engineering Management, 46(2), 245-257. https:/ / doi.org/10.1109/17.797966

Wiengarten, F., Pagell, M., Ahmed, M.U. \& Gimenez, C., (2014). Do a country's logistical capabilities moderate the external integration performance relationship?. Journal of Operations Management, 32(1), 51-56.

Yousief, N.A.I. (2018). The Relationship between Supply Chain Integration and Operational Performance: The Mediating Role Responsiveness and Technological Capabilities as Moderating Effect (Doctoral dissertation, Sudan University of Science and Technology).

Yuen, K.F., \& Thai, V.V. (2017). The influence of supply chain integration on operational performance: A comparison between product and service supply chains. The International Journal of Logistics Management, 28(2), 444-463. https://doi.org/10.1108/IJLM-12-2015-0241

Zhao, L., Huo, B., Sun, L., \& Zhao, X. (2013). The impact of supply chain risk on supply chain integration and company performance: A global investigation. Supply Chain Management: An International Journal, 18(2),115-131. https://doi.org/10.1108/13598541311318773

Zhao, X., Huo, B., Selen, W., \& Yeung, J. (2011). The impact of internal integration on relationship commitment on external integration. Journal of Operations Management, 29(1-2), 17-32. https://doi.org/10.1016/j.jom.2010.04.004

Journal of Industrial Engineering and Management, 2021 (www.jiem.org)

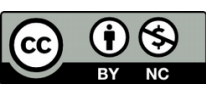

Article's contents are provided on an Attribution-Non Commercial 4.0 Creative commons International License. Readers are allowed to copy, distribute and communicate article's contents, provided the author's and Journal of Industrial Engineering and Management's names are included. It must not be used for commercial purposes. To see the complete license contents, please visit https://creativecommons.org/licenses/by-nc/4.0/. 